\title{
22-23 Eylül 2015 Bodrum Sel Felaketi
}

\author{
Ceyhun ÖZÇELİK ${ }^{1}$ \\ Kader BENLi'²
}

\section{ÖZ}

Taşkınlar kentsel ve kırsal alanlarda önemli zararlara yol açmaktadır. Ülkemiz turizmi açısından büyük bir öneme sahip Bodrum ilçesi de taşkınların bu olumsuz etkilerinden nasibini almaktadır. Yoğun kentsel yapılaşma nedeniyle geçirimsizleşen kentsel doku çarpık kentleşmenin de etkisiyle özellikle kısa süreli sağanaklarda kent hayatını yaşanılmaz hale getiren, ülkemiz turizmine de zarar veren taşkınlara sebep olmaktadır. Yetersiz kentsel alt yapının taşkın yüklerini taşıyabilmesi için gereken mühendislik çalışmaları; kentleşmenin yoğun ve çarpık olması, kamulaştırma maliyetlerinin yüksek olması, görev tanımlarındaki belirsizlikler vb. sebeplerden dolayı gecikmektedir. Özellikle 22-23 Eylül 2015 taşkını, Bodrum şehir merkezini büyük ölçüde etkilemiştir. Bu afet sonucunda; Muğla Valiliğince 266 işyeri, 184 konut, 197 araç, 24 motosikletin zarar gördüğü açıklanmıştır. Bununla birlikte şehir içi yollar kapanmış, drenaj hatları zarar görmüş ve turizm sekteye uğramıştır. 22-23 Eylül 2015 taşkını, meydana geldiği alt havzalar ölçeğinde incelenmiştir. Yerinde gözlemler yapılarak taşkın sebep, oluşum ve sonuçları araştırılmıştır. Her bir alt havza için; üst, orta ve alt havza drenaj sistemleri ve bu sistemler üzerindeki yapısal ve yapısal olmayan unsurlar özellikle taşkın oluşturacak sebepler bakımından değerlendirmeye tabi tutulmuştur. Yağış kayıtları kullanılarak, SCS (Soil Conservation Service) modeli aracılığıyla yüzeysel akış tahminleri gerçekleştirilmiştir. Boyutsuz hidrograflar yardımıyla taşkın hidrografları elde edilmiştir. Sonuçlar kullanılarak 22-23 Eylül 2015 taşkını hakkında değerlendirmelere yer verilmiş ve çözüm önerilerinde bulunmuştur.

Anahtar Kelimeler: Taşkın, 22-23 Eylül, hidrograf, SCS modeli, boyutsuz hidrograf, Bodrum.

\footnotetext{
Not: Bu yazı

- Yayın Kurulu’na 26 Aralık 2018 günü ulaşmıştır. 17 Temmuz 2019 günü yayımlanmak üzere kabul edilmiştir.

- 31 Temmuz 2020 gününe kadar tartışmaya açıktır.

- https://dx.doi.org/10.18400/tekderg.503017

1 Muğla Sıtkı Koçman Üniversitesi, Coğrafi Bilgi Sistemleri ve Uzaktan Algılama Uygulama ve Araştırma Merkezi, Muğla - cozcelik@mu.edu.tr - https://orcid.org/0000-0003-4111-2562

2 Dokuz Eylül Üniversitesi, İnşaat Mühendisliği Bölümü, İzmir - kaderbenli48@gmail.com https://orcid.org/0000-0002-7768-6317
} 


\begin{abstract}
Bodrum September 22-23, 2015 Flood Disaster

Floods cause significant damages in urban and rural areas. Bodrum city is of high importance for the tourism of Turkey. It suffers unavoidably from floods. Short duration severe storms incited by impervious surfaces cause immense floods, paralyzing city life as well as the tourism of the country. Engineering studies are hampered by intensive and improper urbanization, expensive expropriation costs and the difficulties in sharing responsibilities among governmental organizations. The flood of 22-23 September 2015 hit the city center of Bodrum, affected many structures and endangered human life. Some city roads were closed, some drainage lines were damaged and tourism was interrupted. The flood of Bodrum on September 22-23, 2015 was investigated on the scale of the affected basins. The causes and consequences of the flood were elucidated by field examinations. The drainage systems of upper, middle and lower basins were evaluated regarding their effects on the impact of the flood. Based on the rainfall records, runoff estimations were obtained using the SCS abstraction methodology. Flood hydrographs were derived by means of dimensionless hydrographs. Obtained results were used for the evaluation of the flood, and for suggesting solutions.
\end{abstract}

Keywords: Flood, 22-23 September, hydrograph, dimensionless hydrograph, SCS model, Bodrum

\title{
1.GİRİS
}

Taşkınlar, özellikle kentsel alanlarda önemli hasarlara neden olan, mal kaybına yol açan ve insan yaşamını da tehdit eden doğal afetlerdir (Linsley, 1986). Söz konusu bu zararlar, yapısal olan ve yapısal olmayan mühendislik çözümleriyle en aza indirgenmeye çalışılmaktadır (Knight, 2006). Ancak, kentsel yapılaşmanın yoğun olduğu ve dolayısıyla havza üzerine düşen yağışın büyük bir kısmının akışa geçtiği bölgelerde, gerek yoğun yapılaşma nedeniyle inşaat faaliyetlerindeki zorluklar gerekse büyük taşkın debilerinin getirdiği ekonomik olmayan çözüm seçenekleri nedeniyle taşkınlara karşı gerekli önlemlerin alınmasında ve uygun mühendislik çözümlerinin geliştirilmesinde ciddi zorluklar yaşanmaktadır (Miller vd., 2014; Linsley, 1982). Maksimum yıllık toplam yağışı en fazla olan bölgelerin başında bulunan ve ülkemiz turizmi açısından önemli bir yere sahip Bodrum, hemen her yıl sel baskınlarıyla karşı karşıya kalmaktadır. Özellikle kısa süreli sağanaklar, çoğunluğu kentsel geçirimsiz örtüyle kaplı havzalarda taşkınlara dönüşerek taşkın zararlarına neden olmaktadır. Bu zararlar, kentsel alt ve üst yapıya hasar vermekle beraber, bölgedeki turizm faaliyetlerinde ve yatırımlarda aksamalara yol açmaktadır. Teknik ve idari sorumluluk Bodrum Belediyesi, Muğla Büyükşehir Belediyesi, Devlet Su İşleri, Orman Bölge Müdürlüğü vb. kurumlar arasında tartışma konusu yapılırken, sorunun asıl kaynağı olarak da yıllar boyunca oluştuğu öne sürülen çarpık kentleşme gösterilmektedir. Çözüm önündeki en önemli engelin ise yüksek kamulaştırma maliyetinin olduğu öne sürülmektedir. 22-23 Eylül 2015 taşkını, Bodrum şehir merkezini önemli ölçüde etkilemiş, bir çok işyeri, konut ve araç zarar görmüştür. Çalışma kapsamında 22-23 Eylül 2015 Bodrum taşkını sebep, oluşum ve sonuçları açısından incelenmiştir. Yerinde gözlemler ve taşkın anına ait sağnak kayıtları kullanılarak elde edilen taşkın hidrografları üzerinden taşkın etkileri üzerinde değerlendirmelere yer verilmiştir. 


\section{2. ÇALIŞMA ALANI VE VERÍLER}

Bodrum; Ege Bölgesi'nde, Muğla sınırları içerisinde kuzeyde Güllük, güneyde Gökova Körfezi arasında bulunan yarımadada yer almaktadır. Kıyı şeridi boyunca iç kesimlere uzanan irili ufaklı bir çok havza barındırmaktadır. Bu havzalardaki akışların taşıdığı alüvyonların oluşturduğu önemli ovalar; Bitez Ovası, Akçaalan Ovası ve Karaova'dır. İlçenin yaklaşık \% 60'ı ormanlarla kaplı olup yaygın kızılçam, meşe, palamut, yabani çilek, mersin, sandal ağaçları ve makilik-fundalık alanlarla örtülüdür. Yüzölçümü yaklaşık olarak $560 \mathrm{~km}^{2}$ ve kıyı uzunluğu 175 km'dir. Toplam nüfus 160000 civarında olup, yaz aylarında bu nüfusun 1 milyonun üzerine çıktığı ifade edilmektedir. Akdeniz ve Ege iklim kuşağının hâkim olduğu Bodrumda yaz ayları sıcak, kış ayları serin ve yağışlıdır. 22-23 Eylül 2015 taşkınından etkilenen alan Şekil 1'de sunulmuştur.

22-23 Eylül 2015 tarihine ait MGM (Meteoroloji Genel Müdürlüğü)'den temin edilen eklenik yağış gözlemleri incelendiğinde Plüvyometre ve Plüvyograf kayıtlarının tutarlı olmadığı ve sırasıyla $231.9 \mathrm{~mm}$ ve $206.3 \mathrm{~mm}$ değerlerini gösterdiği belirlenmiştir. Plüvyograflı ölçüm düzeneğinde arıza olduğu bildirildiğinden hesaplamalarda plüvyometre kayıtları kullanılmıştır.
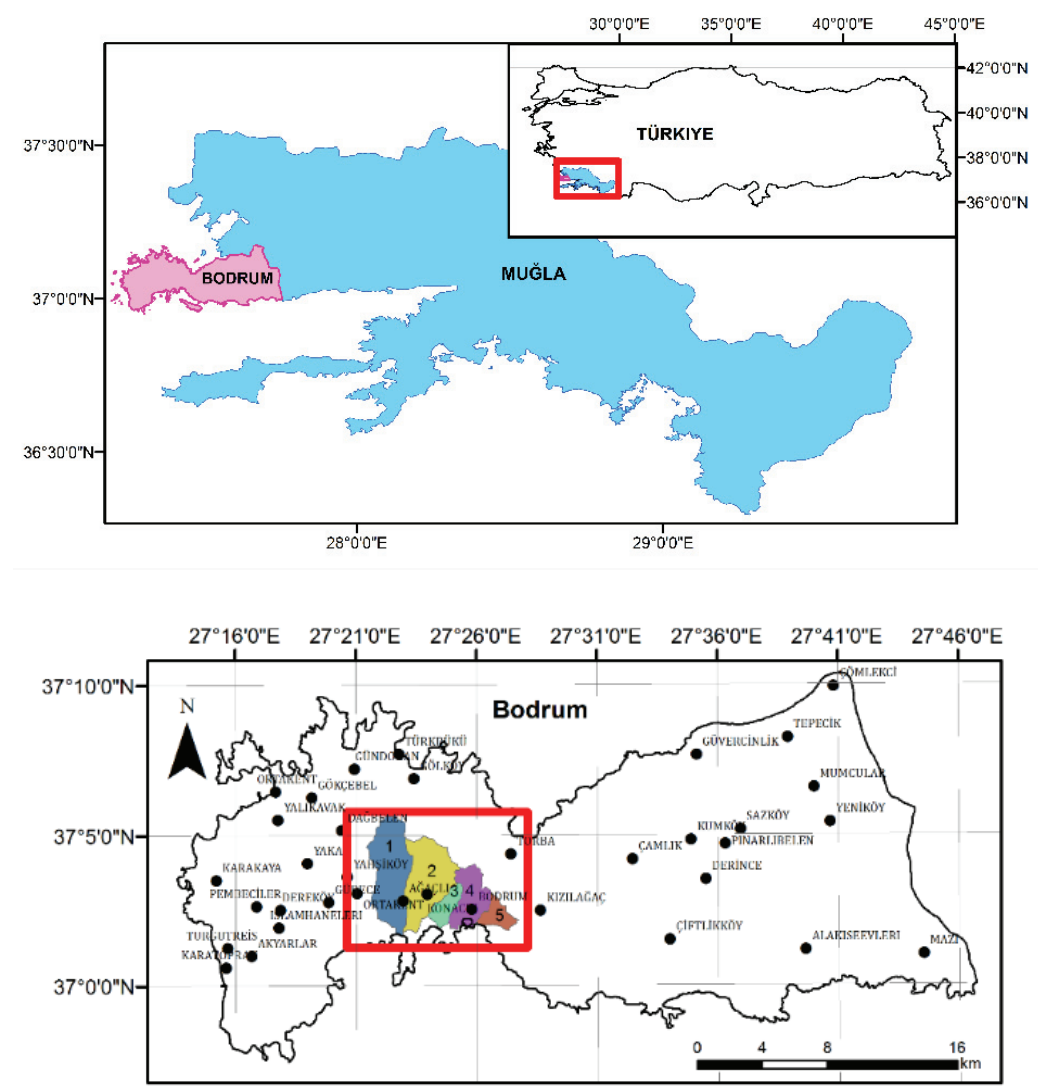

Şekil 1 - Çalışma alanı 

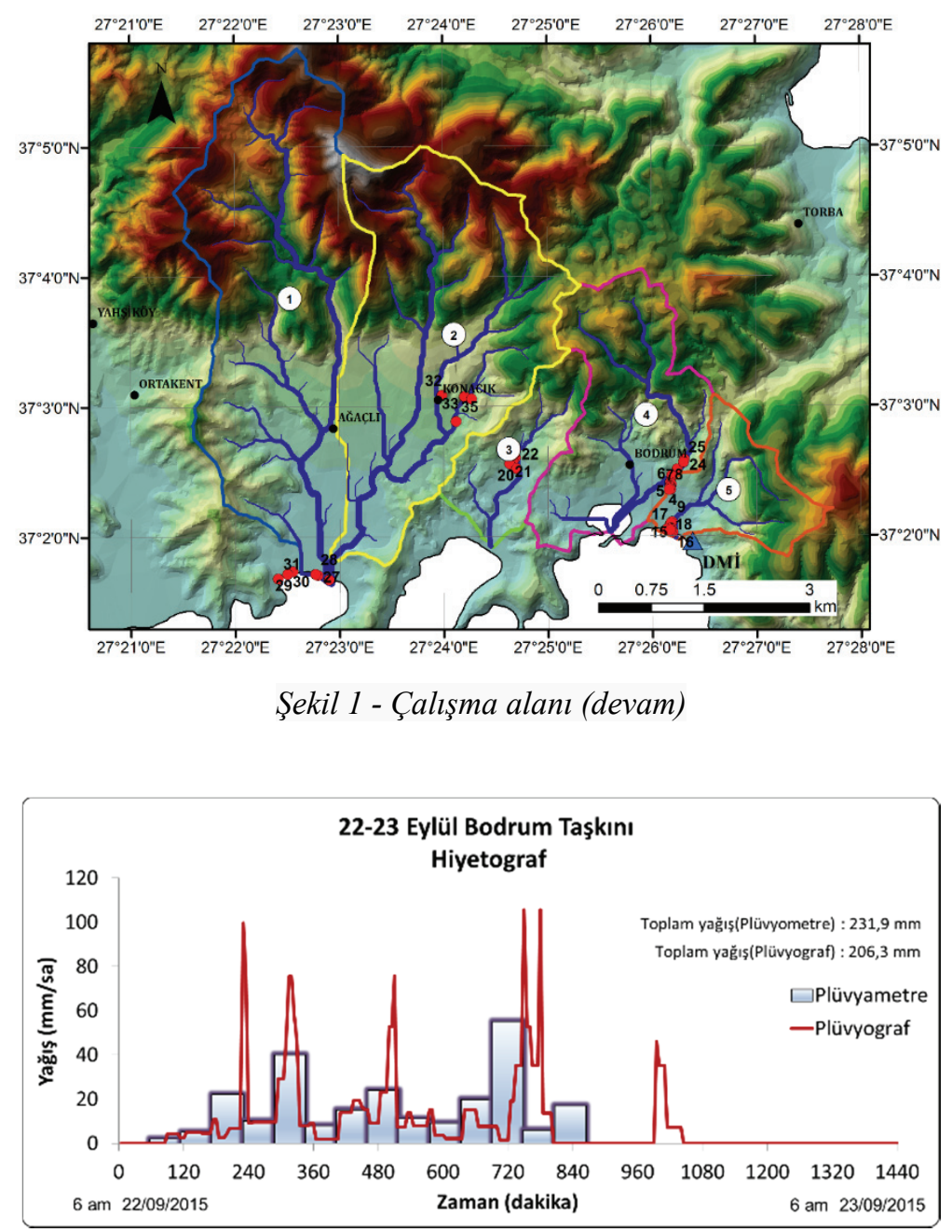

a)

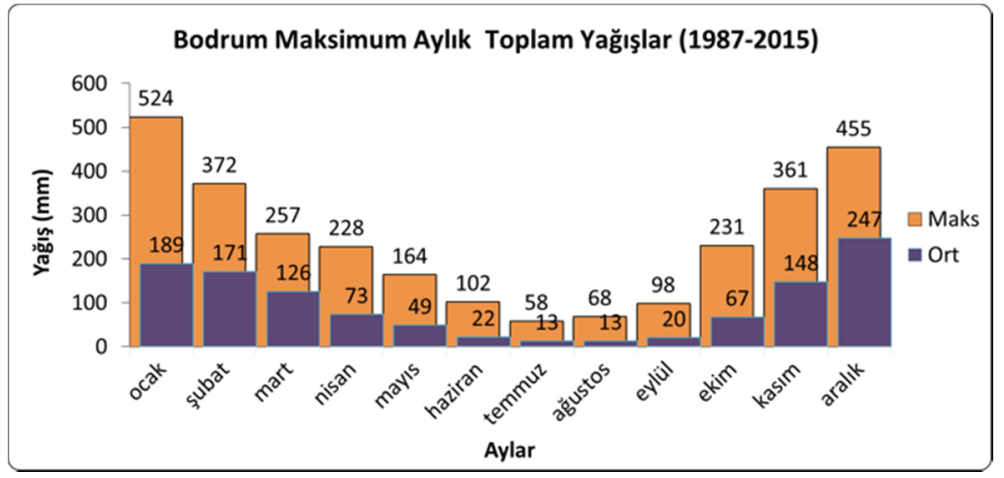

b)

Şekil 2 - Yağış hiyetografları ve istatistikleri 
Eklenik yağış gözlemleri kullanılarak elde edilen hiyetograflar ve bölgenin uzun dönem maksimum toplam aylık yağışlarının maksimum ve ortalama değerleri Şekil 2'de verilmiştir. 22-23 Eylül Bodrum taşkını sırasında, Eylül ayı baz alındığında bir ayda gelebilecek maksimum toplam yağışın üç katının bir günde geldiği, Ekim ayı baz alındığında bir ayda gelebilecek maksimum toplam yağışın bir günde geldiği görülmektedir.

Sayısal Yükselti Modeli için Harita Genel Komutanlığı'nın bölgeye ait 1/25000'lik topoğrafik haritalarından yararlanılmıştır. Arazi kullanımları görsel bantta Landsat uydu görüntüleri kullanılarak elde edilmiştir. Arazi gözlemleri sırasında taşkın zararlarının olduğu bölgeler ve bu zararlara neden olduğu düşünülen faktörler belirlenerek model ortamında vektörel olarak işaretlenmiştir. Söz konusu bölgelerde, afetin etkilerinin önemli olduğu noktaların konumları Şekil 1 ve 3 (kırmızı noktalar) sunulmuştur.

\section{YÖNTEM}

\subsection{Hidrolojik Analizler}

Bodrum genelinde taşkın zararları farklı havzalarda yer alan bilinmesi, ölçülmesi ve modellenmesi pratikte oldukça zor olan lokal faktörlerden kaynaklanmaktadır. Bu faktörlerin herbiri farklı ana havzalar için münferit unsurlardır. Bu nedenle, tüm havzalarda oldukça geniş bir alana yayılı bulunan bütün lokal ve genel faktörlerin yeterli çözünürlükte bununla beraber tüm havza parametrelerinin ve fiziksel özelliklerinin tam olarak bilinmesini gerektiren, oluşturulması oldukça pahalı ve zahmetli taşkın simülasyon modelleri kullanılmamıştır. 22-23 Eylül 2015 taşkınının büyüklüğünü ve diğer karakteristik özelliklerini yansıtması bakımından her havzada taşkın hidrografları sentetik yöntemlerle elde edilerek, taşkın sonrası gözlemler ve taşkının yıkıcı etkilerini oluşturan unsurlar ışığında değerlendirilmiştir.

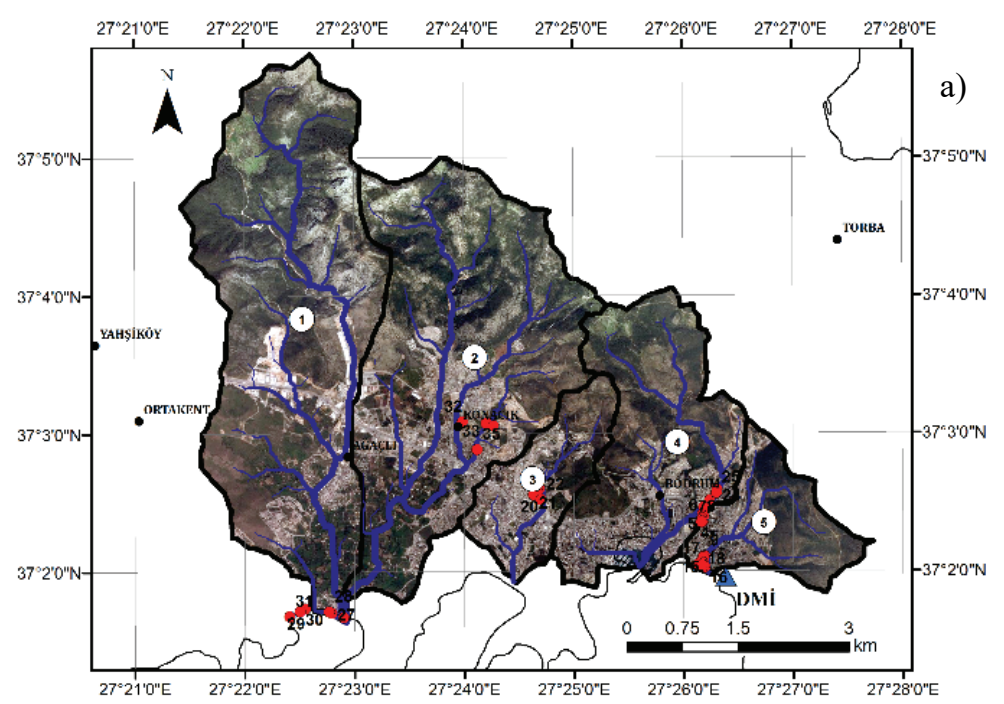

Şekil 3 - Taşkın havzası haritaları; (a) Uydu görüntüsü, (b) Arazi kullanımı, (c) Yükselti haritası, (d) Eğim haritası 


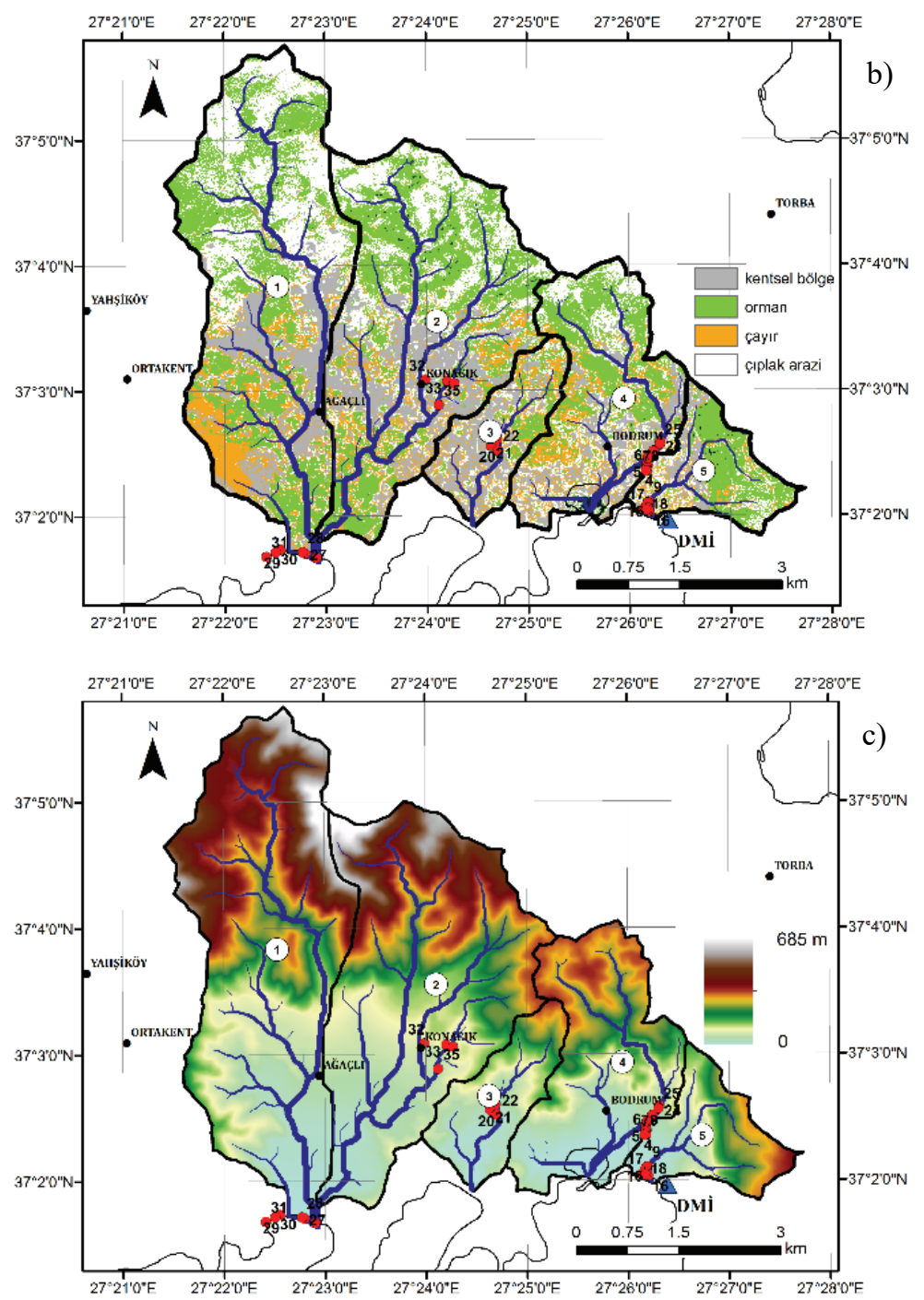

Şekil 3 - Taşkın havzası haritaları; (a) Uydu görüntüsü, (b) Arazi kullanımı, (c) Yükselti haritası, (d) Ĕ̈im haritası (devam)

Taşkın hesaplarında kullanılmak üzere ilk olarak taşkın gözlenen havzalar hidrolojik olarak Coğrafi Bilgi Sistemleri (CBS) ortamında modellenmiştir. $\mathrm{Bu}$ maksatla, bölgenin 1/25000'lik sayısal topoğrafik haritası kullanılmış, raster ve tin formatlarında Sayısal Yükseklik Modeli ve Sayısal Arazi Modeli elde edilmiştir. Sonrasında Coğrafi Bilgi Sistemleri analizleri ile havza sınırları haritası, akarsu ağı haritası, havzanın eğim haritası, arazi kullanım haritası elde edilmiştir (Şekil 3) 


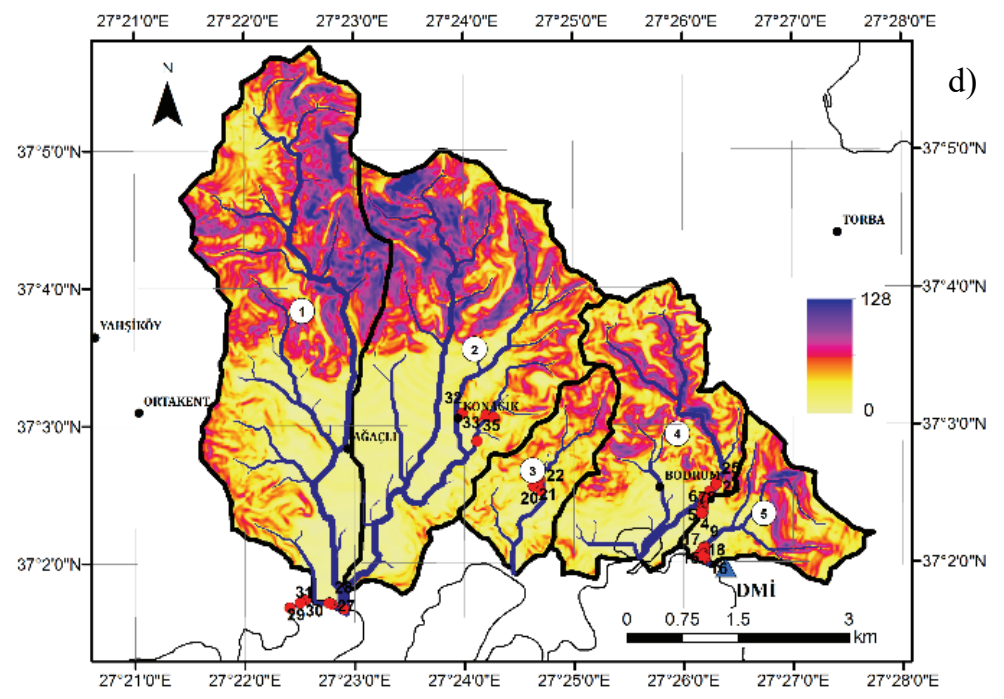

Şekil 3 - Taşkın havzası haritaları; (a) Uydu görüntüsü, (b) Arazi kullanımı, (c) Yükselti haritası, (d) Ĕgim haritası (devam)

Arazi kullanım haritası, 3 band RGB (Red, Green, Blue yani Kırmızı, Yeşil, Mavi) görüntü dikkate alınarak Maksimum Likelihood Yöntemi kullanılarak oluşturulmuştur. Arazi sınıfları SCS akış eğrilerinin belirlenmesine esas olan arazi kullanım türleri baz alınarak belirlenmiştir (Mishra ve Singh 2003). Bu haritalar dolaysız yüzeysel akışın ve akış hidrograflarının türetilmesinde kullanılmışlardır. Coğrafi Bilgi Sistemi Modeli kullanılarak taşkın havzaları belirlenmiştir. Taşkın etkilerinin görüldüğü Bodrum şehir merkezini kaplayan 5 ana havza için analizler gerçekleştirilmiştir (Şekil 3). Bu havzaların özellikleri Çizelge 1'de verilmiştir.

\section{Çizelge 1 - Havza Özellikleri}

\begin{tabular}{c|cccccc} 
Havza no & $\begin{array}{c}\text { Alan } \\
\left(\mathbf{k m}^{\mathbf{2}}\right)\end{array}$ & $\mathbf{h}_{\text {ort }}(\mathbf{m})$ & $\mathbf{L}(\mathbf{k m})$ & $\mathbf{H}(\mathbf{m})$ & $\mathbf{S}_{\mathbf{1}}(\mathbf{\%})$ & $\mathbf{S}_{\mathbf{2}}(\mathbf{\%})$ \\
\hline 1 & 13.3 & 226.4 & 7.5 & 336 & 4.5 & 29.9 \\
2 & 12.2 & 199.1 & 6.6 & 330 & 5.0 & 26.5 \\
3 & 2.7 & 82.6 & 2.85 & 230 & 8.1 & 20 \\
4 & 6.3 & 132.2 & 4.15 & 228 & 5.5 & 24 \\
5 & 2.6 & 131.1 & 2.65 & 230 & 8.7 & 24.9 \\
\hline
\end{tabular}

\section{Parametreler}

A: havza alan1;

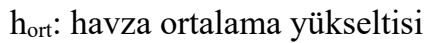

L: ana dere uzunluğu;
$\mathrm{H}$ : havza giriş çıkış arası kot farkı

$\mathrm{S}_{1}$ : ortalama ana yatak eğimi;

$\mathrm{S}_{2}$ : ortalama havza eğimi 
SCS akış eğrilerinin belirlenmesinde $\mathrm{P}_{\mathrm{e}}$ etkili yağış, $\mathrm{P}$ toplam yağış yüksekliği, $\mathrm{S}_{\mathrm{o}}$ maksimum potansiyel yüzeysel biriktirme olmak üzere;

$\mathrm{P}_{\mathrm{e}}=\left(\mathrm{P}-0.2 \mathrm{~S}_{\mathrm{o}}\right)^{2} /\left(\mathrm{P}+0.8 \mathrm{~S}_{\mathrm{o}}\right)$

$\mathrm{S}_{\mathrm{o}}=(25400 / \mathrm{CN})-254 \quad(\mathrm{~mm})$

eşitlikleri kullanılmıştır (Chow vd., 1988; Rawls vd, 1981; SCS, 1965). Şekil 3d'de sunulan arazi kullanım türleri ve yerinde gözlemlerle belirlenen zemin grupları baz alınarak, her bir havza için arazi kullanım yüzdeleri, arazi kullanımlarına karşılık gelen akış eğri numaraları ve havzaların ortalama akış eğri numaraları hesaplanarak Çizelge 2'de sunulmuştur.

Çizelge 2 - Arazi Sınıflarına Göre Bölgesel Akış Ĕ̆ri Numaraları

\begin{tabular}{|c|c|c|c|c|c|c|c|c|c|c|c|c|}
\hline & \multicolumn{4}{|c|}{ Havza 1} & \multicolumn{4}{|c|}{ Havza 2} & \multicolumn{4}{|c|}{ Havza 3} \\
\hline Zemin Grubu & & B & ( & C & & 3 & ( & C & 1 & B & ( & C \\
\hline Arazi türü & $\%$ & $\mathrm{CN}$ & $\%$ & $\mathrm{CN}$ & $\%$ & $\mathrm{CN}$ & $\%$ & $\mathrm{CN}$ & $\%$ & $\mathrm{CN}$ & $\%$ & $\mathrm{CN}$ \\
\hline Endüstriyel bölge & 3 & 88 & 3 & 91 & 1 & 88 & 1 & 91 & & & & \\
\hline Kentsel geçirimsiz alanlar & 2 & 98 & 2 & 98 & 2 & 98 & 2 & 98 & 2 & 98 & 2 & 98 \\
\hline Yerleşim bölgesi (\%38 geçirimsiz) & 11 & 75 & 11 & 83 & 19 & 75 & 19 & 83 & & & & \\
\hline Yerleşim bölgesi (\%65 geçirimsiz) & & & & & & & & & 16 & 85 & 16 & 90 \\
\hline Çıplak arazi, mera,(kötü) & 10 & 79 & 10 & 86 & 5 & 79 & 12 & 86 & 8 & 79 & 8 & 86 \\
\hline Çayır (iyi koşul) & 16 & 58 & & & 7 & 58 & 7 & 71 & & & 14 & 71 \\
\hline Orman & 12 & 66 & 18 & 77 & 7 & 66 & 17 & 77 & & & 34 & 77 \\
\hline Bölgesel akış eğri numarası, CN & & & & 76 & & & & 78 & & & & 81 \\
\hline Yüzeysel biriktirme, So (mm) & & & & 79 & & & & 72 & & & & 58 \\
\hline
\end{tabular}

Çizelge 2 - Arazi Sınıflarına Göre Bölgesel Akış Ĕ̆ri Numaraları (devam)

\begin{tabular}{|c|c|c|c|c|c|c|c|c|}
\hline \multirow[b]{2}{*}{ Zemin Grubu } & \multicolumn{4}{|c|}{ Havza 4} & \multicolumn{4}{|c|}{ Havza 5} \\
\hline & \multicolumn{2}{|c|}{$\mathrm{B}$} & \multicolumn{2}{|c|}{$\mathrm{C}$} & \multicolumn{2}{|c|}{$\mathrm{B}$} & \multicolumn{2}{|c|}{$\mathrm{C}$} \\
\hline Arazi türü & $\%$ & $\mathrm{CN}$ & $\%$ & $\mathrm{CN}$ & $\%$ & $\mathrm{CN}$ & $\%$ & $\mathrm{CN}$ \\
\hline Endüstriyel bölge & & & & & & & & \\
\hline Kentsel geçirimsiz alanlar & 08 & 98 & 8 & 98 & 3 & 98 & 3 & 98 \\
\hline Yerleşim bölgesi (\%38 geçirimsiz) & & & & & & & & \\
\hline Yerleşim bölgesi (\%65 geçirimsiz) & 11 & 85 & 11 & 90 & 5 & 85 & 5 & 90 \\
\hline Çıplak arazi, mera (kötü) & 11 & 79 & 11 & 86 & 20 & 79 & 20 & 86 \\
\hline Çayır (iyi koşul) & & & 11 & 71 & 11 & 58 & 11 & 71 \\
\hline Orman & 3 & 66 & 27 & 77 & & & 22 & 77 \\
\hline Bölgesel akış eğri numarası, CN & & & & 83 & & & & 79 \\
\hline Yüzeysel biriktirme, So (mm) & & & & 53 & & & & 67 \\
\hline
\end{tabular}


Bölgesel akış eğri numaraları ve maksimum potansiyel yüzeysel biriktirme değerleri kullanılarak (a) yağış - yüzeysel akış eğrileri ve (b) artık yağış hiyetografları elde edilmiştir (Şekil 4).
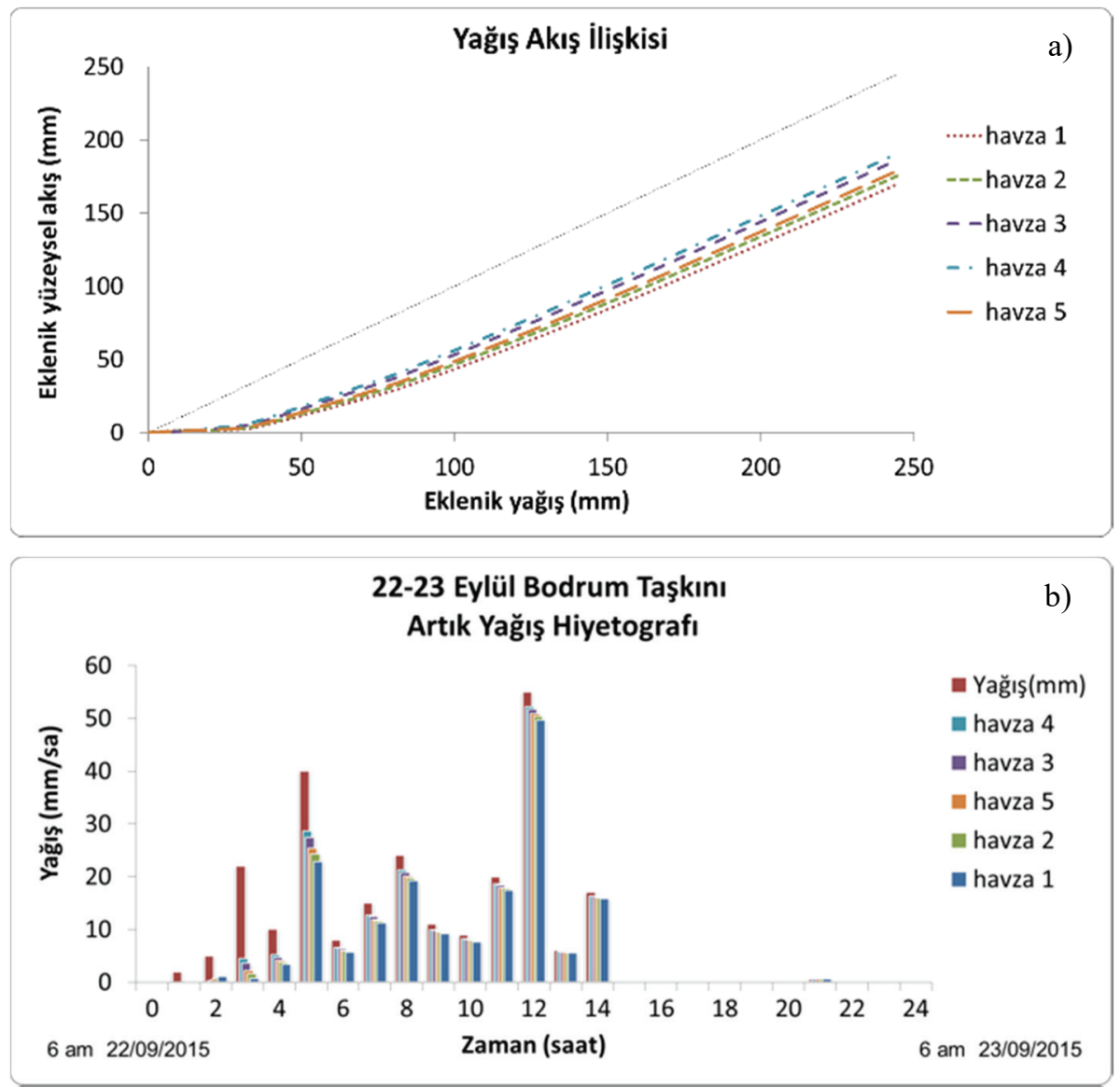

Şekil 4 - (a) Yă̆ış - yüzeysel akış ilişkileri, (b) Artık yă̆ış hiyetografları

22-23 Eylül Bodrum taşkınına ait akış kayıtları bulunmadığından, taşkın debileri sentetik birim hidrograflar yardımıyla hesaplanmıştır. SCS sentetik birim hidrograf yöntemi kullanılmıştır (Chow vd, 1988; SCS 1965).

SCS boyutsuz birim hidrografı Şekil 5 'te sunulmuştur. Burada, $\mathrm{q}_{\mathrm{p}}$ birim hidrograf pik akış değerleri $\left(\mathrm{m}^{3} / \mathrm{s} / \mathrm{cm}\right) ; \mathrm{C}=2.08$ olan bir katsayı; A Havza alanı $\left(\mathrm{km}^{2}\right), \mathrm{T}_{\mathrm{p}}$ pike ulaşma süresi (sa), $t_{p}$ gecikme süresi (sa), $T_{c}$ konsantrasyon süresi (sa), $t_{r}$ etkin yağış süresi (sa) dir.

Yağışın toplanma (konsantrasyon) süresi 3 (üç) farklı yöntemle hesaplanmış olup, sentetik birim hidrografın oluşturulması sırasında bu üç yöntemden elde edilen ortalama değer kullanılmıştır. 


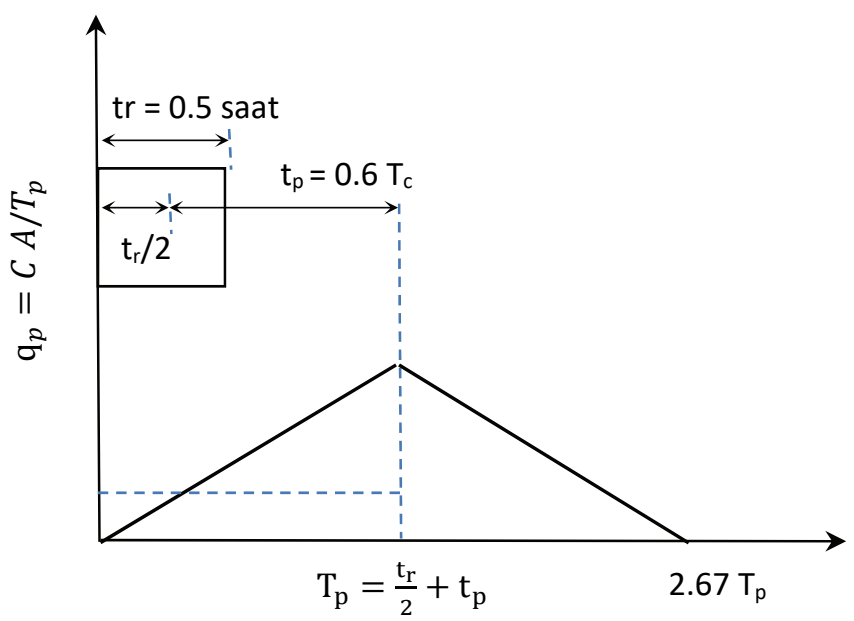

Şekil 5 - SCS Birim Hidrografi

Çizelge 3 - SCS Sentetik Birim Hidrograf Parametreleri

\begin{tabular}{|c|c|c|c|c|}
\hline \multirow{2}{*}{$\begin{array}{c}\text { Havza } \\
\text { no }\end{array}$} & \multicolumn{4}{|c|}{ Konsantrasyon süresi, $T_{c}$ (dakika) } \\
\hline & $\begin{array}{l}\text { Kirpich } \\
(1940)\end{array}$ & $\begin{array}{c}\text { CCP } \\
(1944)\end{array}$ & $\begin{array}{c}\text { SCS } \\
(1973)\end{array}$ & Ortalama \\
\hline 1 & 62.0 & 62.1 & 84.4 & 69.5 \\
\hline 2 & 53.9 & 53.9 & 77.0 & 61.6 \\
\hline 3 & 23.5 & 23.5 & 40.7 & 29.2 \\
\hline 4 & 36.3 & 36.4 & 48.0 & 40.2 \\
\hline 5 & 21.6 & 21.6 & 37.0 & 26.7 \\
\hline \multirow[t]{2}{*}{$\mathbf{T}_{\mathrm{c}}$} & $0.0078 \mathrm{~L}^{0.77} \mathrm{~S}^{-0.385}$ & $60\left(11.9 \mathrm{~L}^{3} / \mathrm{H}\right)^{-0.385}$ & \multicolumn{2}{|c|}{$\begin{array}{c}100 \mathrm{~L}^{0.8}[(1000 / \mathrm{CN})-9]^{0.7} \\
/ 1900 \mathrm{~J}^{0.5}\end{array}$} \\
\hline & $\begin{array}{l}\text { L: Ana yatak } \\
\quad \text { uzunluğu (feet) } \\
\text { S: Ort. havza eğimi }\end{array}$ & $\begin{array}{l}\text { L: En uzun yatak } \\
\text { uzunluğu (mil) } \\
\text { H: Havza giriş çıkış } \\
\text { arası kot farkı } \\
\text { (feet) }\end{array}$ & \multicolumn{2}{|c|}{$\begin{array}{l}\text { L: En uzun yatak uzunluğu } \\
\text { (feet) } \\
\text { S: Ort. havza eğimi, \% } \\
\text { CN: SCS Akış eğri } \\
\text { numarası }\end{array}$} \\
\hline
\end{tabular}

Havza konsantrasyon süreleri Çizelge 3'te, bu hidrografa ilişkin havza bazında elde edilen parametreler Çizelge 4'te sunulmuştur.

Her bir havza için elde edilen birim hidrograflar Şekil 6a'da verilmiştir. Bu birim hidrograflar, artık yağış hiyetograflarının (Şekil 4b) saatlik değerleri kullanılarak ölçeklendirilmiştir. Her bir saat için elde edilen ölçeklendirilmiş birim hidrograf değerleri 
saatlik olarak kaydırılmak suretiyle süperpose edilmiş, böylelikle havzaların taşkın hidrograflarına ulaşılmıştır (Şekil 6b).

\section{Çizelge 4 - SCS Sentetik Birim Hidrograf Parametreleri}

\begin{tabular}{cccc}
\hline \multirow{2}{*}{ Havza no } & \multicolumn{3}{c}{ Parametre } \\
\cline { 2 - 4 } & $\mathrm{t}_{\mathrm{p}}=0.6^{*} \mathrm{~T}_{\mathrm{c}}(\mathrm{saat})$ & $\mathrm{T}_{\mathrm{p}}(\mathrm{saat})$ & $\mathrm{q}_{\mathrm{p}}\left(\mathrm{m}^{3} / \mathrm{s} / \mathrm{cm}\right)$ \\
\hline 1 & 0.695 & 1.19 & 23.15 \\
2 & 0.616 & 1.12 & 22.79 \\
3 & 0.292 & 0.79 & 7.06 \\
4 & 0.402 & 0.90 & 14.48 \\
5 & 0.267 & 0.77 & 7.18
\end{tabular}
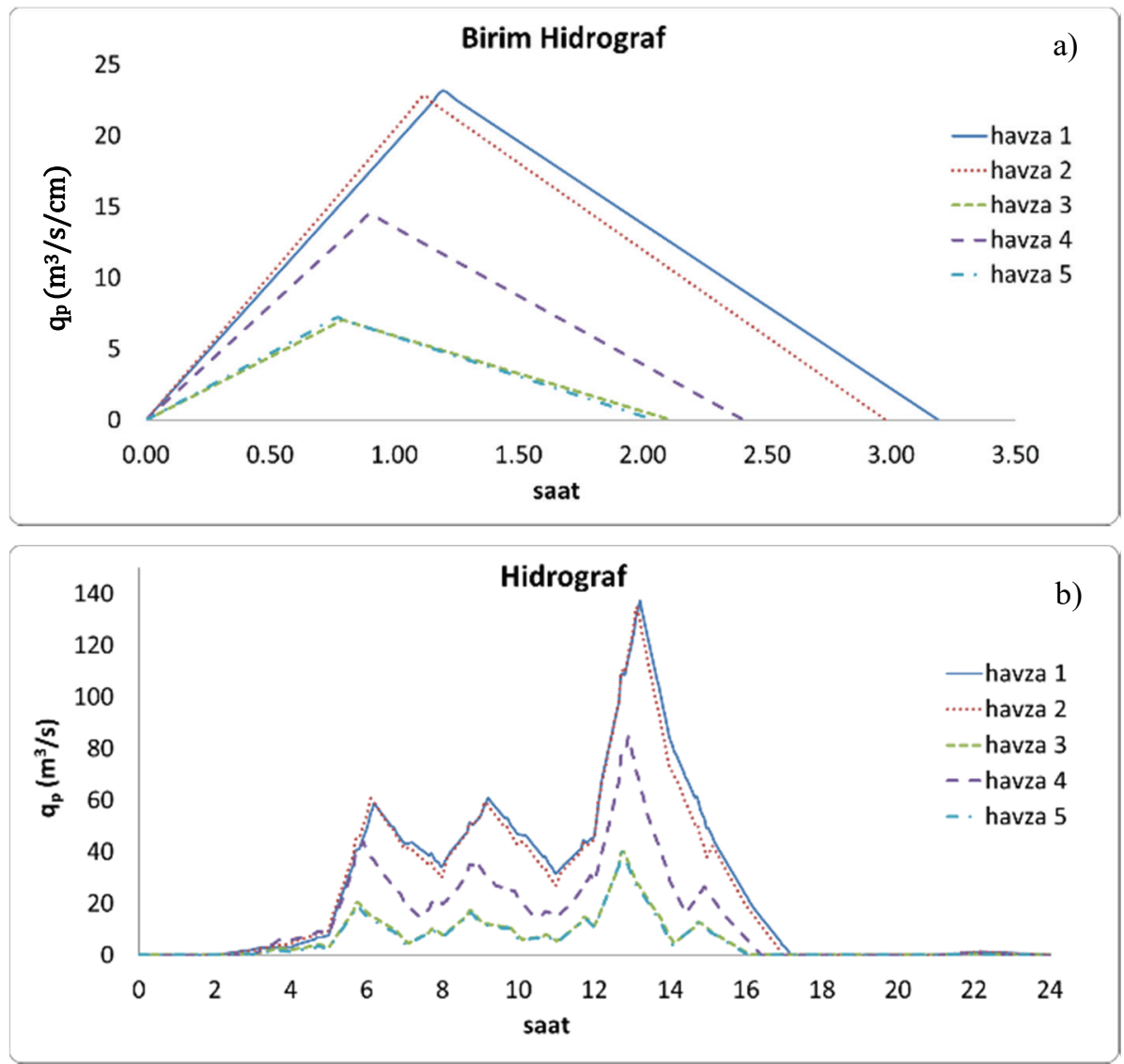

Şekil 6 - a) SCS birim hidrografları, b)Taşkın hidrografları 


\section{2-23 Eylül 2015 Bodrum Sel Felaketi}

En büyük debinin yağışın başlamasından yaklaşık 13 saat sonra oluştuğu; 1 ve 2 numaralı havzalar için $135 \mathrm{~m}^{3} / \mathrm{s}, 4$ numaralı havza için $85 \mathrm{~m}^{3} / \mathrm{s}, 3$ ve 5 numaralı havzalar için $40 \mathrm{~m}^{3} / \mathrm{s}$ civarında olduğu hesaplanmıştır.

\subsection{Arazi Gözlemleri}

Bodrumda taşkın havzalarının alanları oldukça küçüktür. Bu nedenle yağış şiddetinin havza boyunca sabit kabul edilmesi mümkündür. Taşkın havzaları yüksek eğimli olup özellikle ilçe merkezinin hemen hemen yarısı kentsel dokuyla kaplıdır. Geçirimsiz kentsel doku yağışın çok büyük bir kısmının akışa geçmesine sebep olmaktadır. 22-23 Eylül 2015 Bodrum taşkınına ait DMİ Plüvyografının arızalı ölçüm yaptığı bildirilmiştir. Plüvyometre kayıtlarının zamansal çözünürlüğü düşük olup saat mertebesindedir. Sağanaka ait toplam yağış değerleri Plüvyometre ve Plüvyograf için sırasıyla 231.9 mm ve 206.3 mm'dir.

Şiddetli yağışın, yüksek eğimli üst havza boyunca toplanarak az eğimli ve geçirimliliği oldukça düşük alt havzada toplanmasıyla taşkın oluşturduğu gözlenmiştir. (Fotoğraf 1)
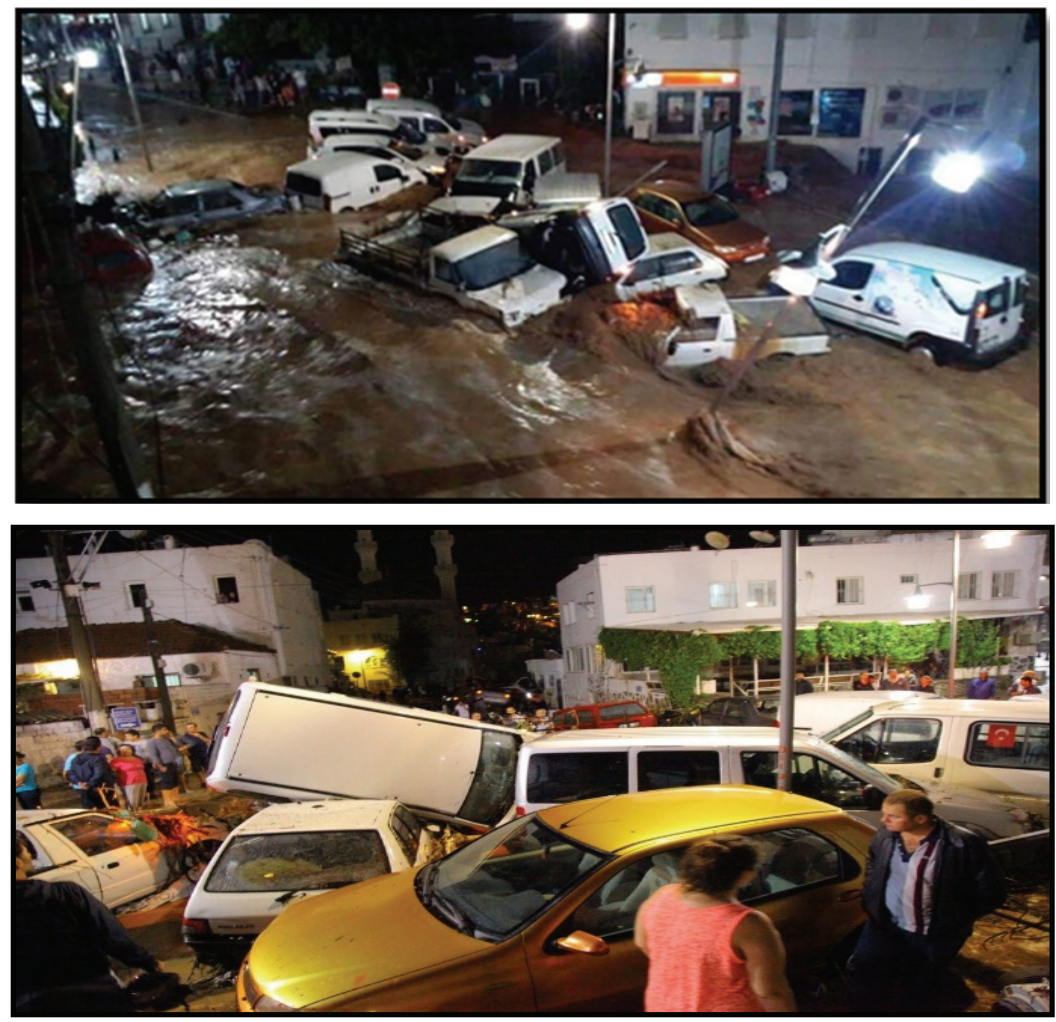

Fotoğraf 1 - Taşkın etkilerine ait fotoğraflar

Çarpık kentleşme ve plansız yapılaşma mevcut drenaj hatlarının kapanmasına, tıkanmasına ve işlevsiz hale gelmesine sebep olarak taşkın şiddetinin artmasına sebep olmuştur. Kurumlar 
arası sorumluluk üstlenilmesindeki politik problemlerin, etkin mühendislik çözümlerinin geliştirilmesine engel olduğu ve sorunun büyük oranda kent içi drenaj kanallarına dolayısıyla kamulaştırma maliyetlerine indirgendiği gözlenmiştir. Altyapı anlamında birçok önemli mühendislik hatalarının yapıldığı tespit edilmiştir. Entegre bir taşkın yönetimine imkan verecek bir altyapı çözümünden çok uzak bir biçimde, noktasal geçici tasarımlarla altyapının tamamen tahrip olduğu gözlenmiştir. 22-23 Eylül 2015 Bodrum taşkını özelinde, taşkın zararlarının büyük oranda yerel çarpık düzensiz kentsel sorunlardan kaynaklandığı tespit edilmiştir. Bu sorunların başlıcaları, aşağıda sunulmuştur.

\section{Dere yatakları üzerindeki yapılaşmalar}

Ana drenaj hatları üzerinde birçok yapılaşma tespit edilmiştir. Bunların en çarpıcısı, İlçe Emniyet Müdürlüğü Binası'nın dere yatağı üzerine inşaa edilmiş olmasıdır (Fotoğraf 2a, 2b, 2c). Taşkın sonrasındaki bulgular, dere yatağının içine müdürlük binasının altına bir kapak yapılarak dere yatağının kapatıldığı yönündedir. Bu kapağın taşkın sırasında kırılarak bir taşkın dalgası ürettiği düşünülmektedir. Kapağın bulunduğu kesit arkasında bir rezervuar oluşmuş, rüsübat birikmesi sonucu tıkanan kapağın kırılmasıyla birlikte kabaca $2000 \mathrm{~m}^{3}$ 'lük bir su saniyeler içinde mansap taşkınına katılmıştır. Bu büyüklükteki bir su taşkını çarptığı cisimlerde onlarca tonluk hidrodinamik etki oluşturmuştur.

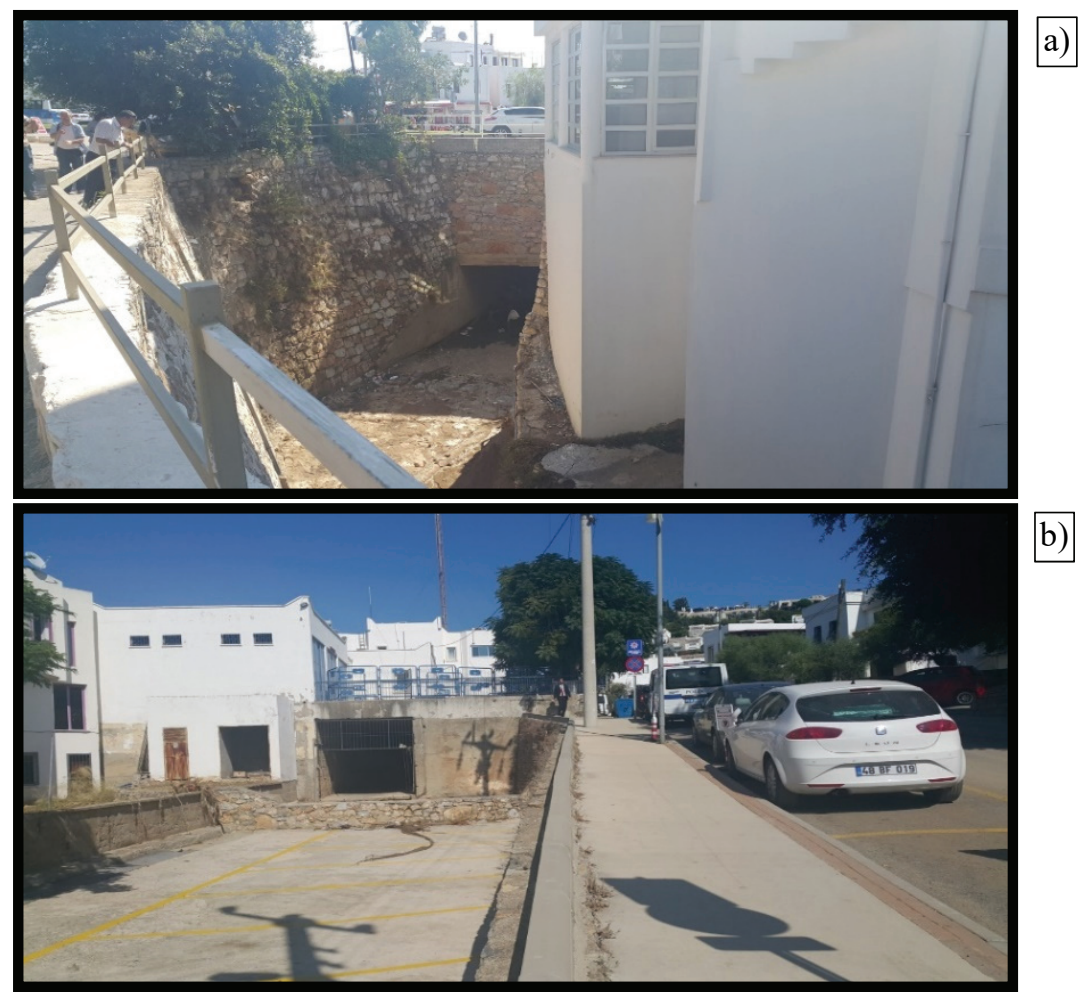

Fotoğraf 2 - Taşkın zararlarına sebep olan başlıca unsurlar (İlçe Emniyet Müdürlüğü Binası) 


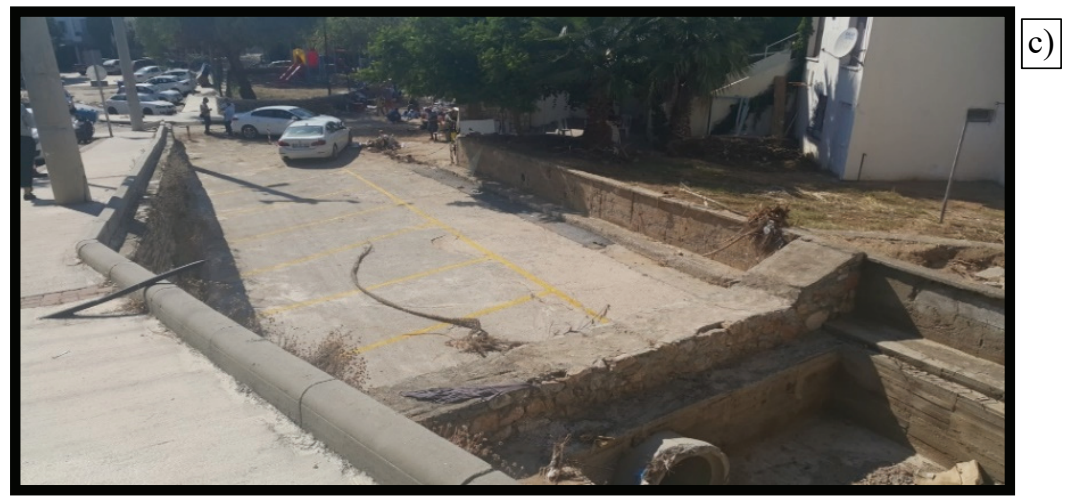

Fotoğraf 2 - Taşkın zararlarına sebep olan başlıca unsurlar (İlçe Emniyet Müdürlüğü Binası) (devam)

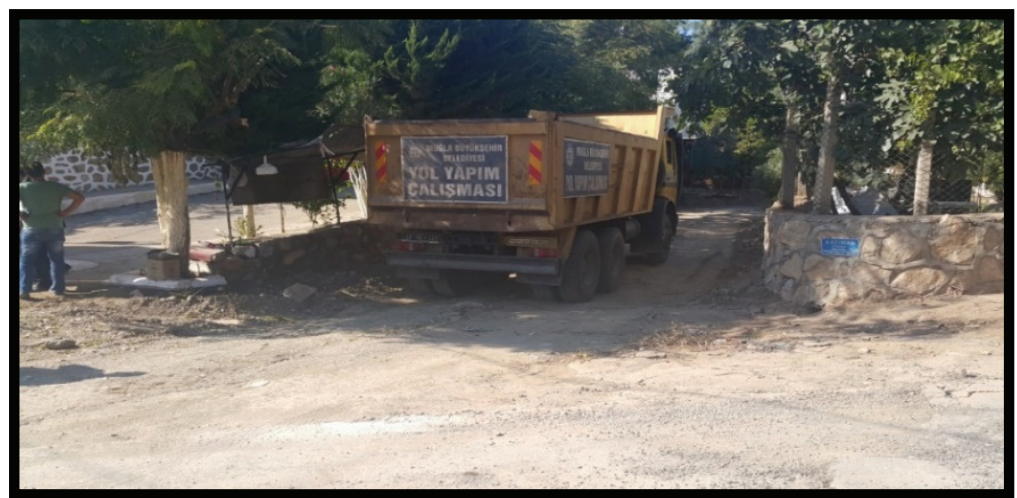

\section{d)}

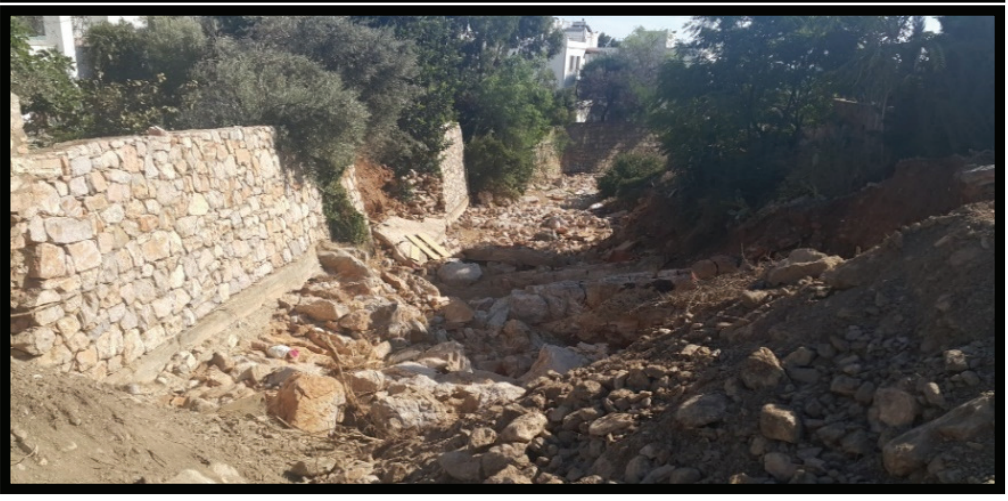

e)

Fotoğraf 2 - Taşkın zararlarına sebep olan başlıca unsurlar (Derenin yol yapılmasi) (devam) 


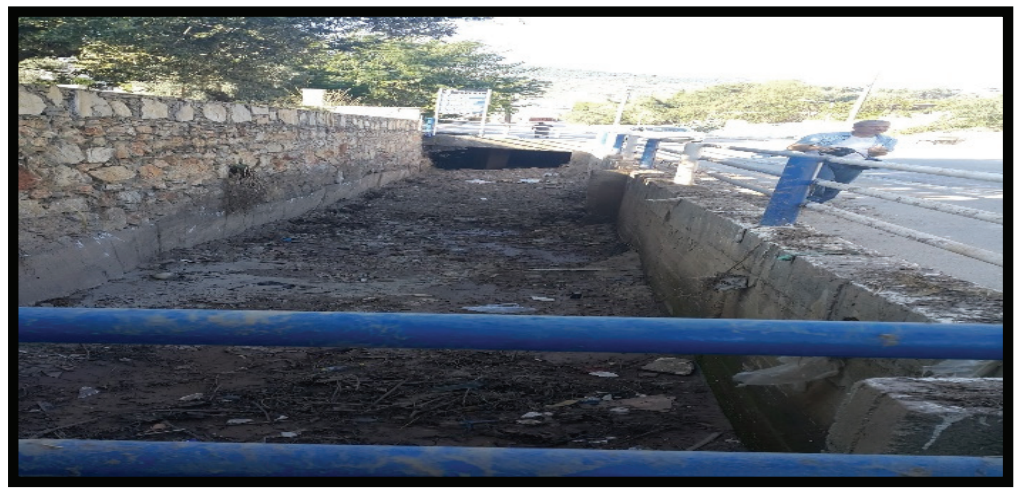

f)

Fotoğraf 2 - Taşkın zararlarına sebep olan başlıca unsurlar (Derenin yol yapılmasi) (devam)

\section{Dere yataklarının yol yapılması}

Taşkının yıkıcı etkisi gözlenen çoğu akış kesitlerinde, dere boyunca gelen suyun aktığı yatağın birden yol olduğu gözlenmiştir (Fotoğraf 2d, 2e, 2f). Dere mecburen yoldan akmak zorunda kaldığından, taşkın oluşması, beklenen bir sonuç olmuştur. Bu yol kesimlerinin çoğunun adı (örneğin dere sokak vb.) zaten o yolun yol değil, dere olduğunu söylemektedir. $\mathrm{Bu}$ kesitlerin derhal akışın sağlanacağı bir biçimde düzenlenmesi gerekmektedir.

\section{Akış güzergahındaki düzensizlikler, ani kesit daralma ve genişlemeler}

Bodrumda havzaların hemen hepsinde dere yataklarının kentsel dokuyla birleştiği noktalarda akış kesitlerinde çok büyük düzensizlikler gözlenmiştir (Fotoğraf 2c, 2f, 2g, 2i). Özellikle dere yataklarının yollarla birleştiği noktalarda dere yatağının $\left(5 \mathrm{~m}^{2}\right.$ ila $\left.20 \mathrm{~m}^{2}\right)$ birden daralarak bir büz bir kutu menfez boyutuna $\left(0.1 \mathrm{~m}^{2}\right.$ ila $\left.4 \mathrm{~m}^{2}\right)$ daralması bir çok örnekte karşımıza çıkmaktadır. Su kesitten geçemeyince, daralan kesit öncesinde kabarıp, taşması normal bir durumdur. 22-23 Eylül 2015 Bodrum taşkınında çoğu zarar bu sebepten gerçekleşmiştir.

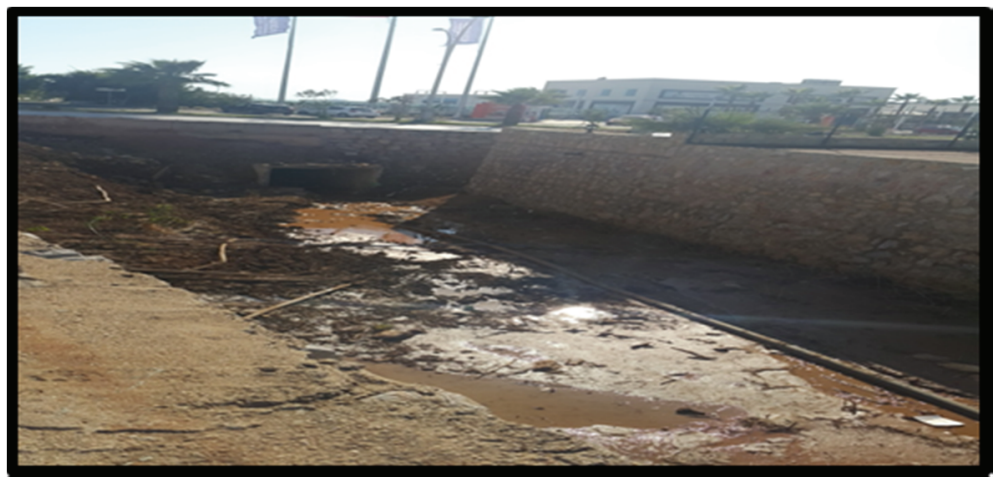

Fotoğraf 2 - Taşkın zararlarına sebep olan başlıca unsurlar (Menfezler) (devam) 


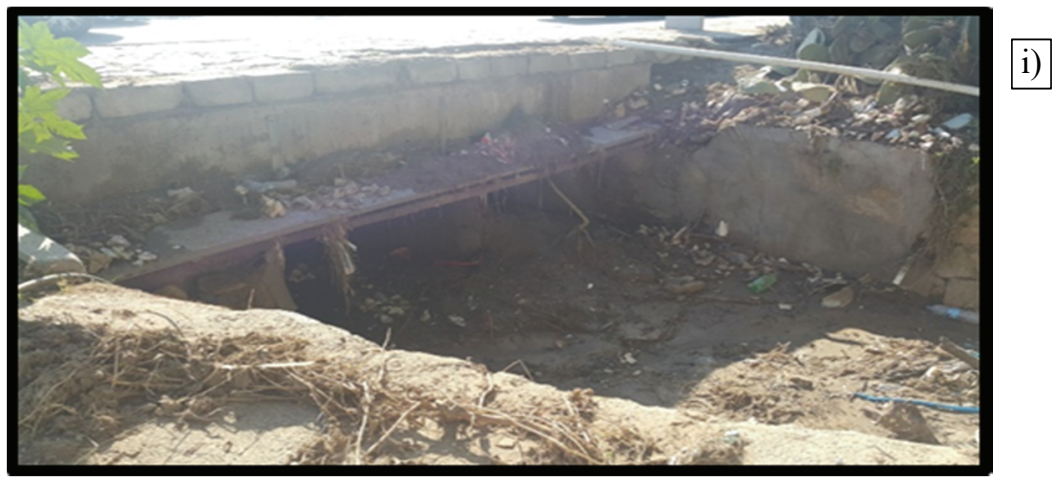

Fotoğraf 2 - Taşkın zararlarına sebep olan başlıca unsurlar (Menfezler) (devam)

\section{Dere yatağına inşaa edilen yan duvarlar}

Kırsal alanlarda ve kırsal alanların kentsel dokuyla birleştiği noktalarda inşaa edilen dere yan duvarlarının büyük bir kısmı taş duvar olarak inşa edilmiştir (Fotoğraf 2a, 2e, 2f, 2g, 2h). Taş duvar inşaasında da birçok uygunsuzluklar olduğu gözlenmiştir. Taş duvarlar çekme gerilmesi taşımayan yapılardır. Bu sebeple bu yapılar önünde biriken su büyük bir hidrostatik kuvvet oluşturarak, yapının yıkılmasına ve kentsel alanların zarar görmesine sebep olmuştur.

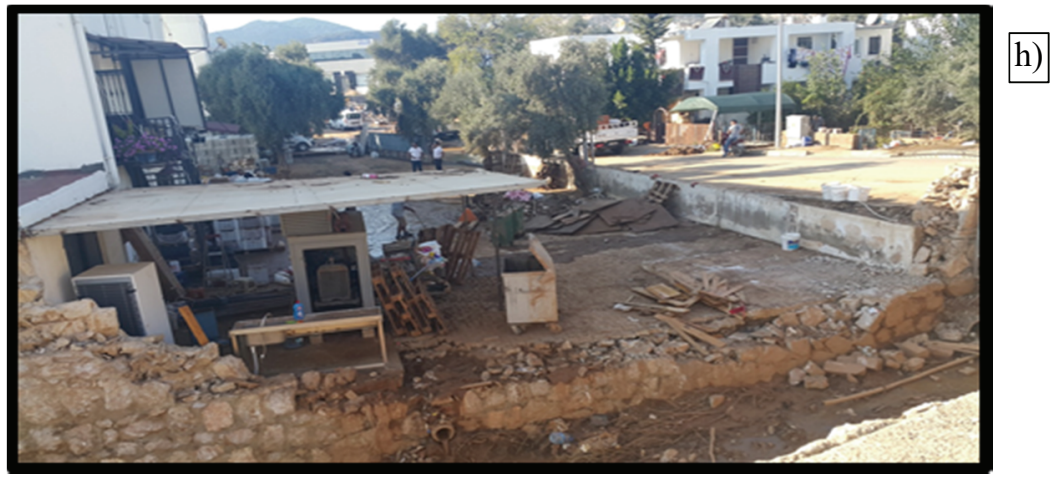

Fotoğraf 2 - Taşkın zararlarına sebep olan başlıca unsurlar (Yan duvarlar) (devam)

\section{Yağmur suyu drenaj sisteminin olmaması ya da yanlış teşkil edilmesi}

Bodrum'da drenaj sistemi doğal drenaj hattı boyunca değil, sokakların inşasına uygun olarak geçirilmeye çalışıldığı tespit edilmiştir. Bu ise drenaj hattı boyunca kesikliklere yol açmıştır (Fotoğraf 2c, 2d, 2f, 2g). Geniş kesitlerden dar kesitlere, dar kesitten tekrar geniş kesitlere geçen uyumsuz bir hat söz konusudur. Yağmur suyu sistemleri serbest akışlı ve maksimum \%80 dolulukla çalışması mümkün olan sistemlerdir. Oysa drenaj hattı boyunca yağış sularını basınçlı akmaya zorlayan birçok yapı söz konusudur. Suyun basınçlı akması mazgallardan yağmur sularının ve atık suların kentsel alanları basması sonucunu doğurmuştur. 


\section{Mevcut drenaj hatlarının çoğu tıkalı olması}

Drenaj kanallarının çoğunun tıkalı ve zaten tıkanmaya müsait bir biçimde inşaa edilmiş olduğu belirlenmiştir (Fotoğraf 2f, 2g, 2i). Tıkanma oluşturacak kesimlerin düzenlenerek tıkanmaların önüne geçilmesi, hattın düzenli aralıklarla tıkanmaya karşı kontrolünün ve temizliğinin yapılması gereklidir.

\section{Taşkın tutma seddi}

Bitez'de taşkın tutma rezervuarı olarak kullanılan bir yığma seddenin olduğu gözlenmiştir (Fotoğraf 2j). Bu seddenin yıkılmasıyla, Bitez tarihinin en büyük taşkınlarından birinin yaşanması muhtemeldir. Yağmur sularının tutma havuzlarında tutularak taşkın pik değerinin düşürülmesi akılcı bir yöntem olmakla beraber, belirli bir projeye uygun olmadan rastgele toprak yığılmasıyla oluşturulan bir rezervuar seddesinin yıkılması binlerce metreküplük suyun saniyeler içerisinde büyük felakete dönüşmesine sebep olacaktır.

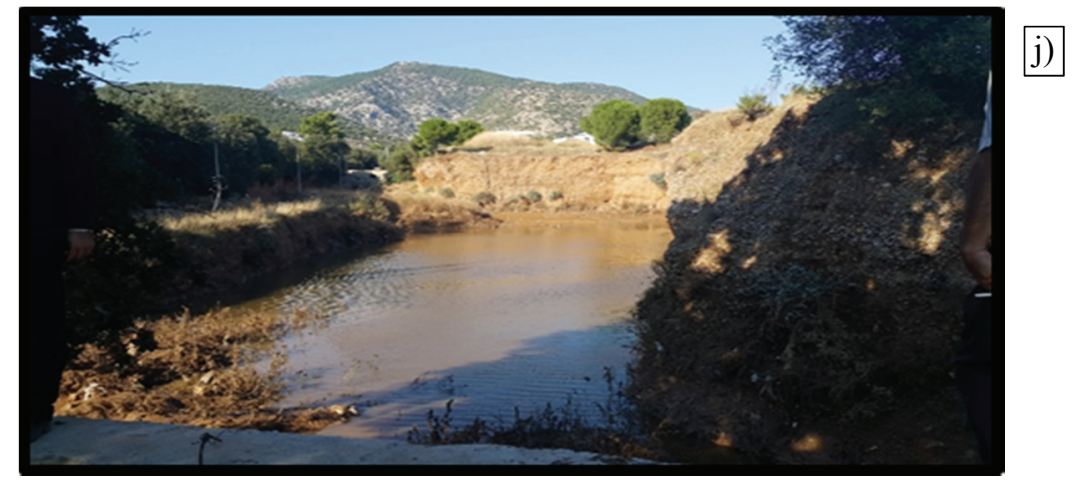

Fotoğraf 2 - Taşkın Zararlarına Sebep Olan Başlıca Unsurlar (Tutma Seddi) (devam)

\section{DEĞERLENDİRMELER}

22-23 Eylül 2015 Bodrum sel felaketinde sağanak yağış, Bodrum ilçe sınırları içerisindeki irili ufaklı havzalarda dolaysız akış oluşturarak, doğal ve yapay drenaj sistemi bulunan noktalarda drenaj hattı boyunca taşmak suretiyle, bulunmayan noktalarda ise doğrudan arazi üzerinde ilerleyerek büyük tahribata yol açmıştır. İlgili plüvyograf ölçümlerinin sağlıklı yapılamaması, yağışın zamansal dağılımının düşük çözünürlükte belirlenebilmesine neden olmuştur. Bodrum DMI istasyonu kentsel alanda, 5 numaralı havza içerisinde ve ölçüm hatalarına sebep olabilen çevresel faktörlerden etkilenebilecek bir konumdadır (Şekil 1). Bölgenin eğimli ve topoğrafyanın değişken olması, yağışın alansal dağılımını da önemli kılmaktadır. Plüvyometre kayıtları esas alınarak yapılan hesaplamalarda 1, 2, 3, 4 ve 5 numaralı havzalarda beklenen maksimum akışların, sırasıyla 137.2, 134.8, 40.1, 84.7 ve 40.0 $\mathrm{m}^{3} / \mathrm{s}$ olduğu ve yağışın başlamasından yaklaşık 13 saat sonra oluştuğu belirlenmiştir. Taşkın sırasında gözlenen toplam yağış yüksekliğinin uzun yıllar aylık maksimum toplam yağış değerlerinin üst sınırlarına yakın olmasının yanında (Şekil 2), havzaların büyük oranda (Çizelge 2) geçirimsiz olması, teknik altyapının düzensiz olması ve mühendislik 
çözümlerinin geliştirilememiş olması taşkının yıkıcı etkilerini ortaya çıkaran en önemli etkenler olmuştur.

Taşkın hidrografları ve yerinde gözlemler göz önünde bulundurulduğunda taşkının yıkıcı etkilerinin taşkın pik debilerinin en fazla olduğu 1 ve 2 numaralı havzaların aksine, $40.1 \mathrm{~m}^{3} / \mathrm{s}$ ve $84.7 \mathrm{~m}^{3} / \mathrm{s}$ olduğu 3 ve 4 numaralı havzalarda gerçekleştiği gözlemlenmiştir. Bu etkilerin sirasıyla OASISS AVM önünde Bodrum ana kara yolunun kapanmasına sebep olan 3 numaralı havzadaki yetersiz menfez tasarımı (Şekil 2i) ve İlçe Emniyet Müdürlüğü binasının mansabında yıkıma sebep olan 4 numaralı havzadaki düzensiz altyapı (Şekil 2a, 2b, 2c) ve yapılaşmadan kaynaklandığı değerlendirilmiştir. Bitez sınırlarında yer alan 1 numaralı havzadaki taşkın pik debisinin $137.2 \mathrm{~m}^{3} / \mathrm{s}$ olmasına rağmen meydana gelen zararın daha az olduğu gözlemlenmiştir. Bu havza şehir merkezine kıyasla oldukça geçirimlidir ve sözkonusu taşkına sebebiyet veren yağışın alansal dağılımı uniform değildir. Taşkının geniş cadde ve düzlükler üzerinde yayılması taşkının yüksekliğini ve dolayısıyla yıkıcı etkisini azaltmıştır. 2 numaralı havzada Konacık mevkiinde yine ana yoldan kaynaklı yetersiz menfez boyutlarının yol açtığı etki taşkın zararlarının oluşmasındaki ana etken olmuştur. 134.8 $\mathrm{m}^{3} / \mathrm{s}^{\prime}$ lik taşkın debisinin pik değeri hacmi ve pike ulaşma sürelerinin önemi bu lokal etkilerden kaynaklı problemlerin gerisinde kalmıştır. 1 ve 2 numaralı havza arazi topoğrafyası nedeniyle yer yer birleşme eğiliminde olduğundan, her iki havzayı da göz önüne alan alternatif taşkın koruma önlemlerinin geliştirilmesi mümkündür. 3 numaralı havzada da doğrudan Bodrum karayolunun altına yerleştirilen menfezin $40.1 \mathrm{~m}^{3} / \mathrm{s}^{\prime}$ lik pik debi karşısında yetersiz kalmasından kaynaklı taşkın zararları sözkonusudur. Şehrin tüm ulaşımını felç etmektedir. Bu havzadaki diğer yerel etkiler çok daha az yıkıma sebep olmuştur. 4 numaralı havza ise Yokuşbaşı Mahallesi'nin bulunduğu, $84.7 \mathrm{~m}^{3} / \mathrm{s}^{\prime} l i k$ pik debinin gözlendiği ve taşkından en çok etkilenen bölgedir. İlçe Emniyet Müdürlüğü binasının altında bulunan kanalın çok küçük çaplı kanalizasyon borularına bağlanması sonucu büyük yıkımlar oluşmuştur. 5 numaralı havzada oluşan $40 \mathrm{~m}^{3} / \mathrm{s}$ 'lik debi ciddi taşkın etkilerine neden olmamıştır. Havzaların drenaj alanlarının küçük olması nedeniyle taşkın hacimlerinin çok büyük olmadığı ancak bu hacimleri kontrol altına alabilecek potansiyel rezervuar alanlarının 1 ve 4 numaralı havzalarda kısmen mümkün olduğu saptanmıştır. Tüm havzalar için elde edilen hidrograflar değerlendirildiğinde taşkınların pike ulaşma sürelerinin yağışın zamansal dağılımıyla doğrudan bağlantılı olduğu görülmüştür.

Taşkın hidrograf hesaplamaları yapmaksızın kaba bir yaklaşımla, maksimum $55 \mathrm{~mm} / \mathrm{sa}$ şiddetindeki bir yağışın (Şekil 2a) tamamının akışa geçtiği varsayıldığında $13 \mathrm{~km}^{2}$ 'lik bir havzada yaklaşık $200 \mathrm{~m}^{3} / \mathrm{s}^{\prime}$ lik pik debi oluşacağı kolayca görülebilir. Bu ise ortalama $\% 5$ eğimde ( Çizelge 1) yaklaşık $5 \mathrm{~m}$ genişliğinde $2.5 \mathrm{~m}$ yükssekliğinde bir akış kesitine karşılık gelmektedir. Dolayısıyla, mevcut kent dokusunda bile böyle bir alt yapıyı inşaa etmenin mümkün olabileceği gözükmektedir. Yapısal olmayan bir önlem olarak, yeşil alanların arttırılması ve kentsel alanlarda geçirimliliğinin sağlanması taşkın etkilerini azaltma noktasında en pratik çözümlerdir. Etkisini azalttığınız bir akış için kırsal ve kentsel alanlarda dere yataklarının 1slahı, sel kapanları ve geciktirme/tutma rezervuarları inşaası gibi yapısal önlemleri uygulamak oldukça kolaylaşacaktır.

Bodrum ile ilgili tartışmalar Bodrum Belediyesi, Muğla Büyükşehir Belediyesi, Devlet Su İşleri, Orman Bölge Müdürlüğü vb. kurumlar arasındaki sorumluluk sınırları üzerinde yürütülmektedir. Problemin kaynağının yüksek kamulaştırma maliyetleri olduğu öne sürülmektedir. Bu nedenle taşkın öncesi, taşkın esnası ve taşkın sonrasını da içine alan bir 
taşkın yönetimine esas olacak bir planlama ve sonrasında projelendirilmeyle taşkın zararlarının minimize edilebileceği entegre bir çözüm yaklaşımının geliştirilebilmesi kısa zaman için mümkün gözükmemektedir.

\section{SONUÇLAR}

22-23 Eylül 2015 Bodrum taşkını özellikle 3 ve 4 numaralı havzalarda ciddi zararlara yol açmıştır. Can kaybı olmaması sebebiyle ucuz atlatılmıştır. Hesaplamalar sonucu elde edilen taşkın hidrografları göz önünde bulundurulduğunda, Bodrum merkezi genelinde en fazla $137.2 \mathrm{~m} / \mathrm{s}^{3}$ lik bir debinin geldiği ancak, ana yıkımın $40.1 \mathrm{~m}^{3} / \mathrm{s}$ ve $84.7 \mathrm{~m}^{3} / \mathrm{s}$ 'lik debilerle 3 ve 4 numaralı havzalarda gerçekleştiği belirlenmiştir. Tüm havzalarda taşkın hidrograflarının pik değerlerinin taşkın zararını arttırdı̆̆ı, ancak asıl sorunun taşkın sularının drenajını engelleyen faktörler olduğu saptanmıştır. Yanlış kanal, menfez ve boru hattı tasarımı, yağmur sularının kanalizasyon borularına drenajı, drenaj kanallarında kagir yan duvar kullanımı, kanal ve borulardaki tıkanma ve yapay engeller gibi lokal etkilerin taşkın zararlarında ana rolü üstlendiği belirlenmiş̧tir. Havza drenaj alanlarının küçük olması sebebiyle, taşkınların pike ulaşma sürelerinin yağışla ilişkili olduğu görülmüştür. Taşkın hacimlerinin üst havzalarda tutulması 1 ve 4 numaralı havzalar için mümkün olmakla birlikte ancak kent içi yağmur suyu drenaj sistemleri, kent dışı kuşaklama sistemleri ve diğer yapısal ve yapısal olmayan önlemlerle entegre bir biçimde değerlendirildiğinde uygun bir çözüme ulaşılabileceği düşünülmektedir.

Kapsamlı entegre bir çözüm geliştirilinceye kadar, lokal önlemler derhal alınmalıdır. Taşkın zararlarına sebep olan başlıca etkenlerin menbasında ve mansabında gerekli düşük maliyetli çalışmalar ve projelendirmeler yapılarak gelecek taşkınların muhtemel zararları azaltılmalıdır. Taş duvar seddeleri yapmak ucuz, ancak bilinçsiz yapıldığında bir o kadar da tehlikelidir. Özellikle yüksek su yüküne maruz olabileceği durumlarda yıkılarak büyük taşkın dalgaları üretebilmektedir. Islah çalışmalarında bu hususa önem gösterilmelidir. Dere, yol birleşimlerindeki büz kesitlerinin tamamı gözden geçirilmeli ve en az dere yatağı genişliğinde mümkünse serbest akışa izin verecek şekilde düzenlenmelidir. Dere yataklarında yatay ve düş̧ey kurblar giderilmeli, suyun kabaracağı engeller tespit edilerek kaldırılmalıdır. Akışın sürekliliği sağlanmalıdır. Şehir içi kaplamaları yavaş yavaş geçirimli hale getirilmeli ve yeni yerleşim alanları içerisinde yeterince yeşil alan bırakılmalıdır. Teknik ve idari sorumluluk üzerine yürütülen tartısmalar sonlandırılarak, çözüm odaklı entegre bir yaklaşımla ülkemizin göz bebeği konumundaki turizm için oldukça önemli olan dünyanın dört bir tarafından turist ağırlayan Bodrum'un taşkın zararlarından minimum ölçüde etkilenmesi sağlanmalıdır.

\section{Teşekkür}

Bu çalışma SKV \& CBS\&UZAL Burs Programı kapsamında desteklenmiştir. Muğla Sıtkı Koçman Vakfı, Coğrafi Bilgi Sistemleri ve Uzaktan Algılama Merkez Müdürlüğü'ne ve katkı sağlayan tüm kişi ve kuruluşlara teşekkür eder, taşkın fotoğraflarının teminindeki nazik tutumları için İHA Muğla Temsilcisi Sn Bekir Tosun'a şükranlarımızı sunarız. 


\section{Kaynaklar}

[1] CCP, (1944). "California Culvert Practice (Reprint of a Series of Technical Abstracts from California Highways and Public Works)", California. Division of Highways.

[2] Chow, V.T., Maidment D., and Mays L., (1988). “Applied Hydrology’”, McGraw-Hill.

[3] Kirpich, Z.P., (1940). "Time of Concentration of Small Agricultural Watersheds", Civil Engineering, 10:362.

[4] Knight, D.W., (2006). "River Flood Hydraulics: Theoretical Issues and StageDischarge Relationships”, In: River Basin Modelling for Flood Risk Mitigation, Ed: Knight.

[5] Linsley, R.K., (1986). "Flood Estimates: How Good Are They?', Water Resources Research, 159 - 164 (22).

[6] Linsley, R.K., Kohier, M.A., and Paulhus, J.L.H., (1982). “ Hydrology for Engineers”, Third Edition, McGraw-Hill Book Company, Inc. New York, NY., 484.

[7] Miller, D.M., Kim H., Kjeldsens T. R., Packman J, Grebby S., and Dearden R., (2014). "Assessing the Impact of Urbanization on Storm Runoff in A Peri-Urban Catchment Using Historical Change in Impervious Cover', Journal of Hydrology, 59-70 (515)

[8] Mishra, S.K., , Singh, V.P., (2003) "Soil Conservation Service Curve Number (SCSCN) Methodology', Water Science and Technology Library, 84-146(42).

[9] Rawls, W.J., Shalaby A., and McCuen, R.H., (1981). "Evaluation Of Methods For Determining Urban Runoff Curve Numbers', Transactions of the American Society of Agricultural Engineers, 24 (6):1562-1566.

[10] SCS, (1965). “Urban Hydrology For Small Watersheds, Tech.”, Soil Conservation Services, Washington, 55. 